\title{
Data report: planktonic foraminifer stable isotope results from IODP Hole U1322B' ${ }^{1}$
}

\author{
Qianyu Li, ${ }^{2,3}$ Fan Zheng, ${ }^{4}$ Xinrong Cheng, ${ }^{2}$ and Rong Xiang ${ }^{4}$
}

\section{Chapter contents}

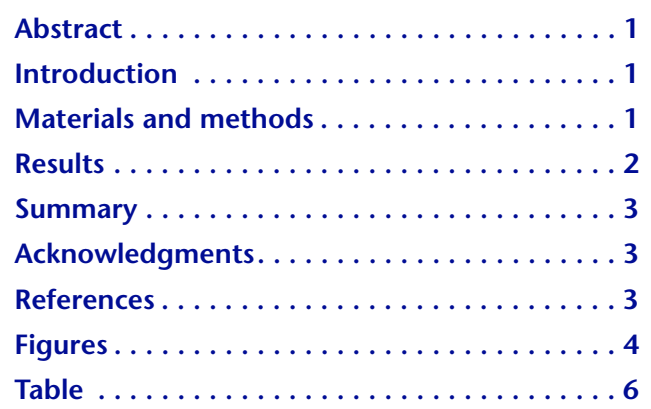

${ }^{1}$ Li, Q., Zheng, F., Cheng, X., and Xiang, R., 2008. Data report: planktonic foraminifer stable isotope results from IODP Hole U1322B. In Flemings, P.B., Behrmann, J.H., John, C.M., and the Expedition 308 Scientists, Proc. IODP, 308: College Station, TX (Integrated Ocean Drilling Program Management International, Inc.).

doi:10.2204/iodp.proc.308.201.2008

${ }^{2}$ State Key Laboratory of Marine Geology, School of Ocean and Earth Sciences, Tongji University, Shanghai 200092, P.R. China. qli01@mail.tongji.edu.cn

${ }^{3}$ Also at: School of Earth and Environmental Sciences, University of Adelaide, Adelaide SA 5005, Australia. qianyu.li@adelaide.edu.au

${ }^{4}$ South China Sea Institute of Oceanology, Chinese Academy of Sciences, Guangzhou 510301, P.R. China.

\begin{abstract}
We measured planktonic foraminifer stable isotopes in samples from Integrated Ocean Drilling Program Hole U1322B in the northern Gulf of Mexico. Among the 97 samples measured, 35 lie in sediment intervals visibly affected by turbidites and 12 are considered affected either by freshwater discharges or by diagenetic overprinting across boundaries between slumped and in situ sediment intervals. Samples affected by freshwater show very light $\delta^{18} \mathrm{O}$ values, whereas those with sudden $\delta^{18} \mathrm{O}$ increases are likely influenced by diagenesis. The remaining 50 measurements appear to represent true hemipelagic $\delta^{18} \mathrm{O}$ records useful for establishing a preliminary oxygen isotopic stratigraphy for the site. Comparison between isotopic results from Hole U1322B and other similar records from the region indicates that the sediment sequence recovered in Hole U1322B was mainly deposited during marine isotopic Stages (MIS) 1, 2, 3, and 4, separable at 23 (MIS 1/2), 89, and 200 meters below seafloor (MIS 3/4), respectively.
\end{abstract}

\section{Introduction}

At a water depth of $1319 \mathrm{~m}$, Site U1322 was the deepest site drilled in the Ursa Basin during Integrated Ocean Drilling Program (IODP) Expedition 308 (Expedition 308 Scientists, 2005). A late Quaternary sediment sequence of $234.5 \mathrm{~m}$ was recovered from Hole U1322B. Complete core recovery made the hole ideal for isotopic analyses. We measured stable isotopes in samples from this hole, aiming to establish an oxygen isotopic stratigraphy for the site and to provide information useful for interpreting paleoenvironmental changes in the region.

\section{Materials and methods}

Hole U1322B $\left(28^{\circ} 5.9642^{\prime} \mathrm{N}, 89^{\circ} 1.4995^{\prime} \mathrm{W}\right)$ is located on the southern slope of the Mississippi Fan in the northern Gulf of Mexico, in a water depth of $1319.5 \mathrm{~m}$ (Expedition 308 Scientists, 2005). The hole penetrated to 234.5 meters below seafloor (mbsf), and core recovery is slightly more than $100 \%$ because of core expansion. The sediment is dominated by dark-colored organic-rich mud accumulated in a rapid depositional environment.

A total of 141 samples $\left(20 \mathrm{~cm}^{3}\right)$, mostly at $1.5 \mathrm{~m}$ spacing, were collected from Hole U1322B. Samples were oven-dried at $60^{\circ} \mathrm{C}$ and 
then washed through a $0.063 \mathrm{~mm}$ sieve. All well-preserved specimens of the planktonic foraminifer Globigerina ruber (clean, intact, with no signs of dissolution) were picked from the $>100-250 \mu \mathrm{m}$ fraction. Specimens $>250 \mu \mathrm{m}$ are extremely rare in most samples. Therefore, only 97 samples yielded 5 or more individuals of $G$. ruber suitable for isotopic measurement.

The specimens picked were washed with ethanol $(\sim 99.7 \%)$ in an ultrasonic bath. They were then dried in an oven at $60^{\circ} \mathrm{C}$ and reacted with orthophosphoric acid in an automated carbonate device (Kiel III) at $70^{\circ} \mathrm{C}$ to generate $\mathrm{CO}_{2}$. Afterward, they were transferred to a Finnigan MAT252 mass spectrometer for measuring stable isotopes in the Laboratory of Marine Geology of Tongji University. Precision was regularly checked with a Chinese national carbonate standard GBW04405; the standard deviation is $0.07 \%$ for $\delta^{18} \mathrm{O}$ and $0.05 \%$ for $\delta^{13} \mathrm{C}$. Finally, a NBS19 standard was used to convert the results to the international Peedee belemnite scale.

\section{Results}

The original planktonic isotope results are shown in Table T1 and plotted in Figure F1. The results show that, in Hole U1322B, samples vary between $-3 \%$ o and $0.5 \%$ for $\delta^{18} \mathrm{O}$ and between $-0.2 \%$ and $1.8 \%$ for $\delta^{13} \mathrm{C}$. The lightest $\delta^{18} \mathrm{O}$ value of about $-3.12 \%$ occurs at 7.85 mbsf, implying the influence of freshwater discharge from the Mississippi River during the early Holocene warm or freshwater plume from the melting of the Laurentide Ice Sheet (Kennett and Shackleton, 1976). At $90.34 \mathrm{mbsf}$, the $\delta^{18} \mathrm{O}$ value is also very low, $-3.0 \%$, likely corresponding to a warm period of marine isotopic Stage (MIS) 3. In contrast, the heaviest value of $0.53 \%$ is found at 86.84 mbsf, probably indicating the Last Glacial Maximum.

Because the sediment sequence recovered in Hole U1322B contains many slumped intervals indicative of mass flow (Expedition 308 Scientists, 2005), 35 samples from these intervals are not considered as being autochthonous and therefore their isotopic results cannot be used. Subsequently, only 62 samples are left to represent the in situ sediment recovered in Hole U1322B (Fig. F1).

However, some of these 62 samples show rapid increases or decreases in $\delta^{18} \mathrm{O}$ values, especially those swift changes to heavier values from immediately below or above slumped sediment layers. Sudden swings in $\delta^{18} \mathrm{O}$ values from tropical areas often characterize glacial-interglacial transitions or short-term climate events, but many such swings on the $\delta^{18} \mathrm{O}$ curve from Hole U1322B appear to be abnormal. Similarly "abnormal" $\delta^{18} \mathrm{O}$ readings, however, are widely reported from the Gulf of Mexico and regions affected by freshwater bursts near big rivers and diagenetic overprinting due to slumps (e.g., Williams and Kohl, 1986; Johnsen et al., 2001). Therefore, 12 such isotopic values from Hole U1322B likely affected by diagenesis (sudden heavy $\delta^{18} \mathrm{O}$ values) and by freshwater (sudden very light $\delta^{18} \mathrm{O}$ values) should be disregarded (Fig. F2).

Apart from the minimum and maximum oxygen isotopic values that respectively denote warm and cold climate stages, a proper designation of MIS for the Hole U1322B record needs comparisons with the global standard as well as other local records. Overall, Hole U1322B $\delta^{18} \mathrm{O}$ and $\delta^{13} \mathrm{C}$ curves can be compared to that of ODP Site 619 (Pigmy Basin) and Core MD03-2642 (Brazos-Trinity Basin \#4) on the Louisiana-Texas continental slope, west of Site U1322 (Fig. F1). A closer examination indicates that the first two are more comparable, but $\delta^{18} \mathrm{O}$ values from Core MD03-2642 are much lighter for the MIS 1-4 interval. Mallarino et al. (2006) attribute the light $\delta^{18} \mathrm{O}$ values in Core MD03-2642 to the use of $<150 \mu \mathrm{m}$ specimens of white and pink G. ruber because small and pink-pigmented specimens often generate lighter isotopic readings.

The modified $\delta^{18} \mathrm{O}$ curve for Hole U1322B using the remaining 50 samples (Fig. F2) shows a better match with the MIS 1-4 interval of the low-latitude isotopic stack (Bassinot et al., 1994). $\delta^{18} \mathrm{O}$ variations follow a trend similar to other curves in indicating a time interval from the last glacial-interglacial cycle since $\sim 70 \mathrm{ka}$. Biostratigraphic results from Hole U1322B also reveal changes in planktonic foraminifer and nannoplankton assemblages with a pattern of "warm $\rightarrow$ cold $\rightarrow$ less warm $\rightarrow$ cold" downhole (Expedition 308 Scientists, 2005). Therefore, these comparable isotopic and biotic results indicate that the sediment sequence recovered in Hole U1322B was largely deposited during MIS 1 through MIS 4 . Respectively, the MIS $1 / 2,2 / 3$, and $3 / 4$ contacts can be drawn close to 23,89 , and 200 mbsf.

Similar to other records from the northern Gulf of Mexico, the Hole U1322B $\delta^{18} \mathrm{O}$ record shows the typical isotopic variation trend found in the tropical-subtropical deep sea (e.g., Bassinot et al., 1994) only after omitting some unusual and unreliable values (Fig. F2). These unusual and unreliable $\delta^{18} \mathrm{O}$ values are interpreted as mainly affected by rapid freshwater discharges from the Mississippi River during ice melting and diagenetic overprinting across boundaries between slumped and in situ sediment intervals. The results from this coarse-resolution 
study help to establish a preliminary oxygen isotopic stratigraphy for Site U1322. A more detailed correlation with high-resolution tropical and high-latitude $\delta^{18} \mathrm{O}$ records requires closer sampling of the sediment section in future studies.

\section{Summary}

Planktonic foraminifer stable isotopes in 97 samples from Hole U1322B were measured, and 62 of them not affected by obvious gravity flow can be used to tighten stratigraphic correlation. A preliminary $\delta^{18} \mathrm{O}$ biostratigraphic framework was established by omitting a further 12 data points affected either by unusually low $\delta^{18} \mathrm{O}$ values likely due to freshwater impact or by rapid $\delta^{18} \mathrm{O}$ increases due to diagenetic overprinting across slumped/unslumped sediment boundaries. Comparison between isotopic results from Hole U1322B and other tropic records from the region indicates that the sediment sequence recovered in Hole U1322B was mainly deposited during MIS 1, 2, 3, and 4, separable at 23 (MIS 1/2), 89 (MIS $2 / 3$ ), and 200 mbsf (MIS 3/4), respectively. A more detailed correlation with other deep sea records requires further high-resolution studies.

\section{Acknowledgments}

This research used samples and data provided by the Integrated Ocean Drilling Program (IODP). We are grateful to the Co-Chief Scientists and all participants of Expedition 308 who helped with the sampling work and provided friendship and support to the senior author during the cruise. We thank Joachim Schoenfeld, Peter Flemings, and Cédric John for valuable comments and suggestions on the manuscript. Funding for this research was provided by IODP China Secretariat and the National Natural Science Foundation of China (grant numbers 40476030, 40576031, and 40631007).

\section{References}

Bassinot, F.C., Labeyrie, L.D., Vincent, E., Quidelleur, X., Shackleton, N.J., and Lancelot, Y., 1994. The astronomical theory of climate and the age of the Brunhes-Matuyama magnetic reversal. Earth Planet. Sci. Lett., 126(1-3):91-108. doi:10.1016/0012-821X(94)90244-5

Expedition 308 Scientists, 2005. Overpressure and fluid flow processes in the deepwater Gulf of Mexico: slope stability, seeps, and shallow-water flow. IODP Prel. Rept., 308. doi:10.2204/iodp.pr.308.2005

Johnsen, S.J., Dahl-Jensen, D., Gundestrup, N., Steffensen, J.P., Clausen, H.B., Miller, H., Masson-Delmotte, V., Sveinbjörnsdottir, A.E., and White, J., 2001. Oxygen isotope and palaeotemperature records from six Greenland ice-core stations: Camp Century, Dye-3, GRIP, GISP2, Renland and NorthGRIP. J. Quat. Sci., 16(4):299-307. doi:10.1002/jqs.622

Kennett, J.P., and Shackleton, N.J., 1975. Laurentide ice sheet meltwater recorded in Gulf of Mexico deep-sea cores. Science, 188(4184):147-150. doi:10.1126/science.188.4184.147

Mallarino, G., Beaubouef, R.T., Droxler, A.W., Abreu, V., and Labeyrie, L., 2006. Sea level influence on the nature and timing of a minibasin sedimentary fill (northwestern slope of the Gulf of Mexico). AAPG Bull., 90(7): 1089-1119. doi:10.1306/02210605058

Shackleton, N.J., Fairbanks, R.G., Chiu, T.-C., and Parrenin, F., 2004. Absolute calibration of the Greenland time scale: implications for Antarctic time scales and for $\Delta^{14}$ C. Quat. Sci. Rev., 23(14-15):1513-1522. doi:10.1016/j.quascirev.2004.03.006

Williams, D.F., and Kohl, B., 1986. Isotope chronostratigraphy and carbonate record for Quaternary Site 619, Pigmy Basin, Louisiana continental slope. In Bouma, A.H., Coleman, J.M., Meyer, A.W., et al., Init. Rept. DSDP, 96: Washington DC (U.S. Govt. Printing Office), 671-676. doi:10.2973/dsdp.proc.96.137.1986

Initial receipt: 16 May 2007

Acceptance: 10 December 2007

Web publication: 5 March 2008

MS 308-201 
Figure F1. Planktonic foraminifer oxygen and carbon isotope results from (A) Hole U1322B (this study), (B) Site 619 (Williams and Kohl, 1986), and (C) Core MD03-2642 (Mallarino et al., 2006). Data points (gray diamonds) from slumped intervals (green shaded areas) in Hole U1322B are omitted from $\delta^{18} \mathrm{O}$ and $\delta^{13} \mathrm{C}$ curves. MIS = marine isotope stage.

\begin{tabular}{l} 
A \\
\\
\hline \\
\hline \\
\hline
\end{tabular}

A
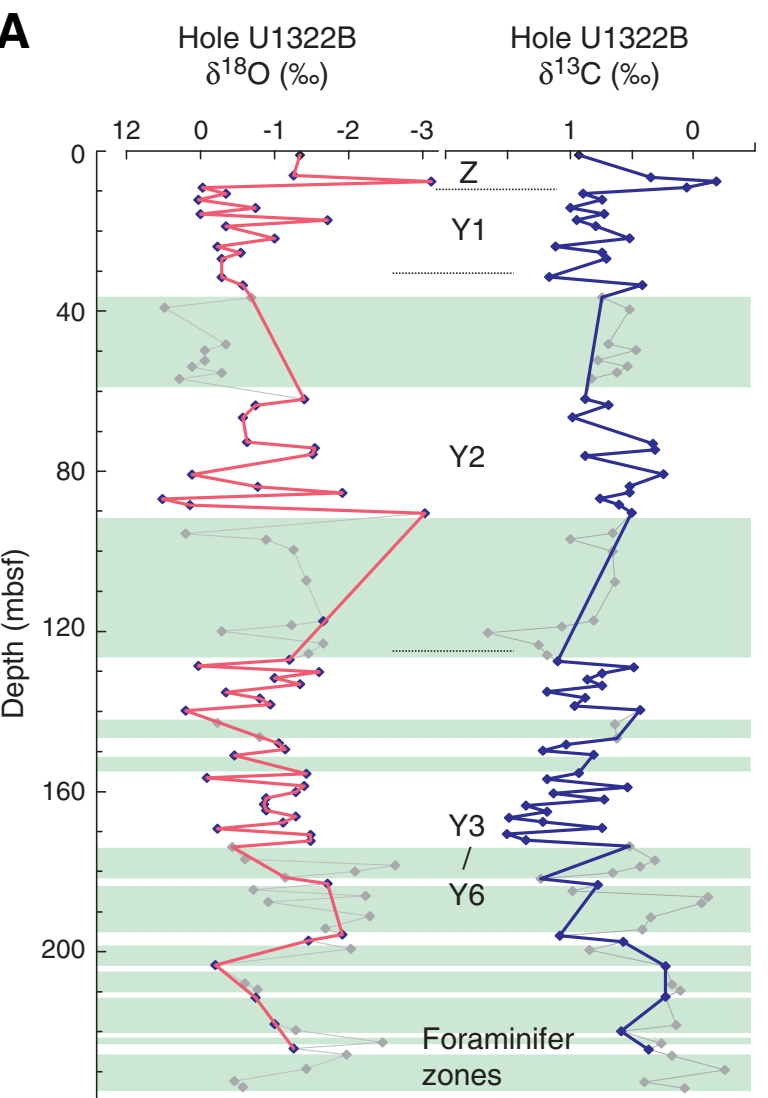

240

Mississippi Fan slope
B
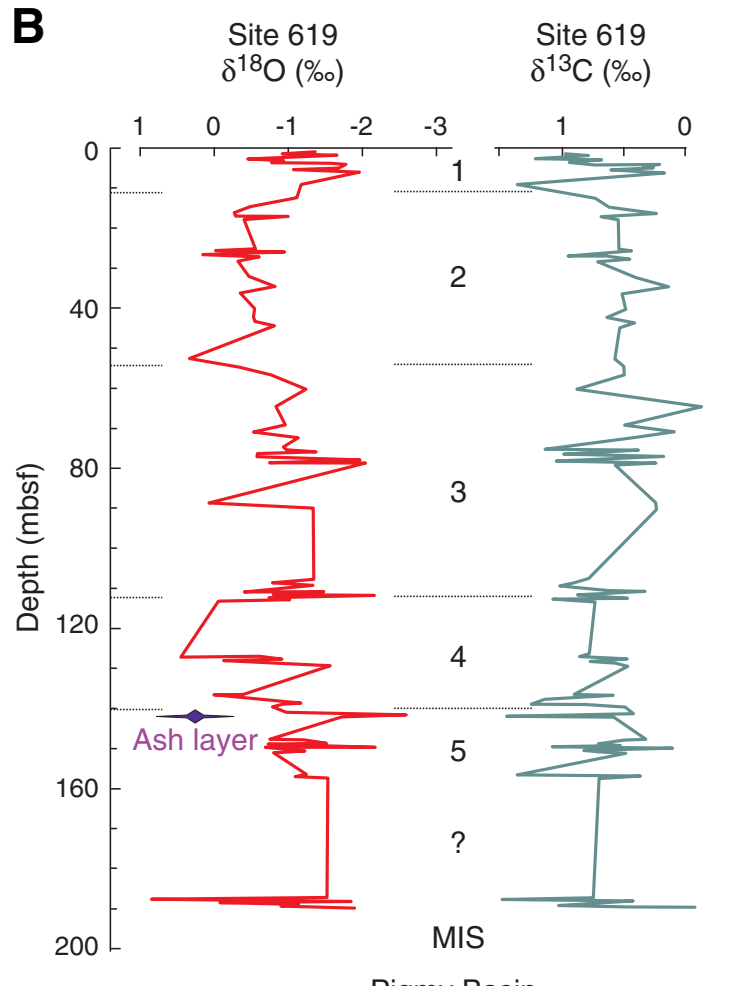

Pigmy Basin
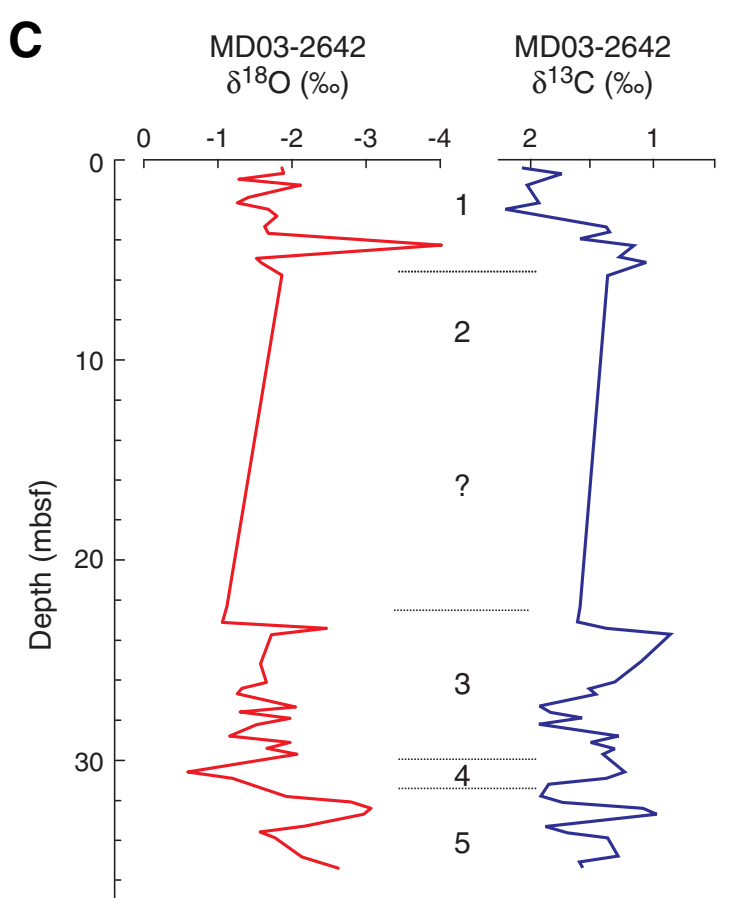

MIS

Brazos-Trinity Basin \#4

Louisiana-Texas continental slope 
Figure F2. Planktonic foraminifer oxygen isotope record from Hole U1322B, as compared to low-latitude isotopic stack (Bassinot et al., 1994) and isotopic-derived paleotemperature record from Greenland ice cores (Johnsen et al., 2001) with age adjusted according to Shackleton et al. (2004). Hole U1322B record has been modified twice: Modified $(1)=$ unusual or unreliable values (gray diamonds) are omitted, Modified $(2)=$ slumped intervals (see Fig. F1) are omitted to show autochthonic hemipelagic $\delta^{18} \mathrm{O}$ readings only. MIS $=$ marine isotope stage. $\mathrm{YD}=\mathrm{Younger}$ Dryas, $\mathrm{D} / \mathrm{O}=$ Dansgaard/Oeschger.
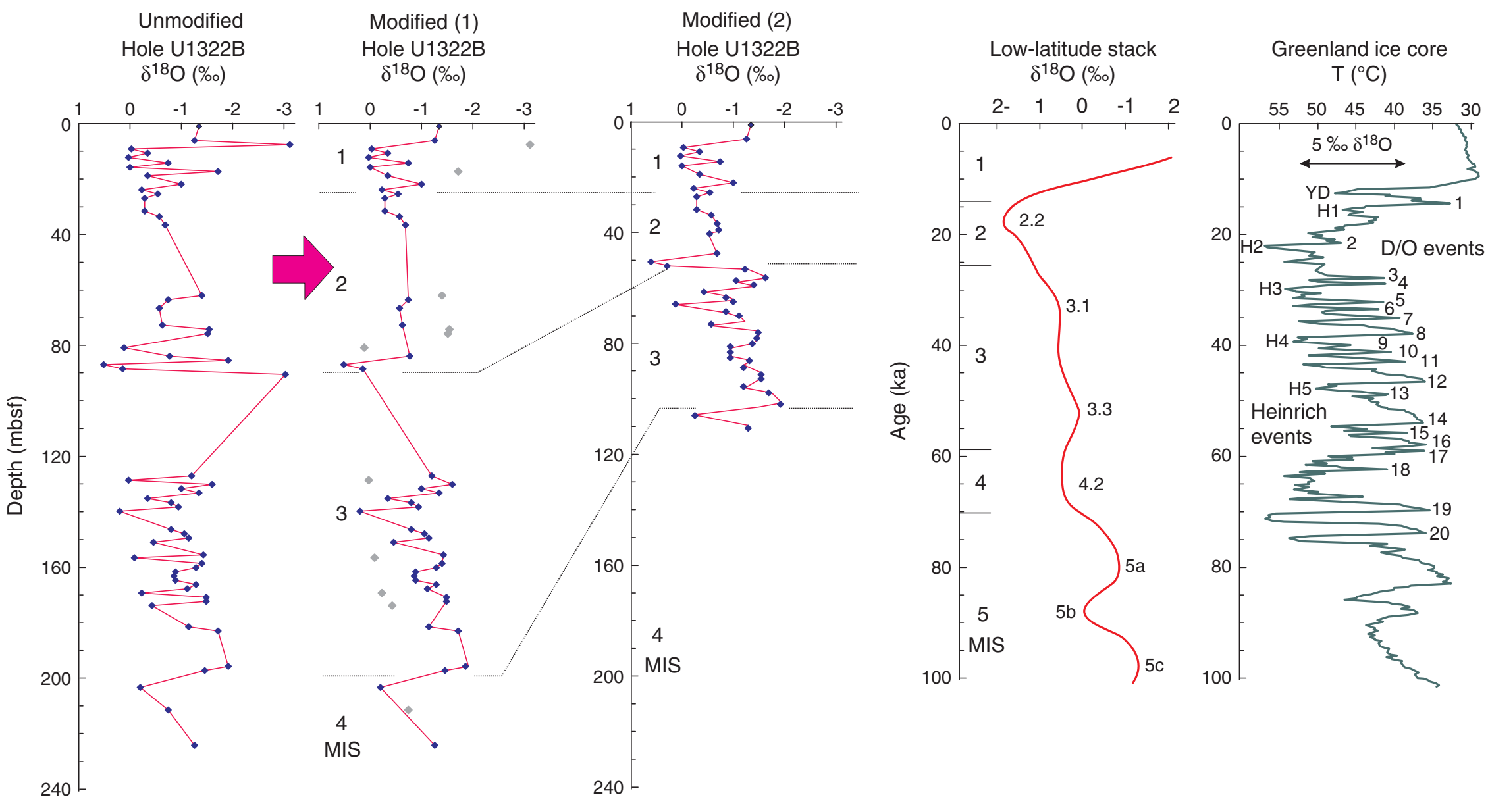
Table T1. Planktonic foraminifer (Globigerinoides ruber, 0.10-0.25 mm) stable isotope data, Hole U1322B.

\begin{tabular}{|c|c|c|c|}
\hline $\begin{array}{l}\text { Core, section, } \\
\text { interval }(\mathrm{cm})\end{array}$ & $\begin{array}{l}\text { Depth } \\
\text { (mbsf) }\end{array}$ & $\begin{array}{l}\delta^{18} \mathrm{O} \\
(\% \mathrm{o})\end{array}$ & $\begin{array}{l}\delta^{13} \mathrm{C} \\
(\% o)\end{array}$ \\
\hline \multicolumn{4}{|l|}{ 308-U1322B- } \\
\hline $1 \mathrm{H}-1,84-89$ & 0.84 & -1.35 & 0.93 \\
\hline $2 \mathrm{H}-2,85-89$ & 6.35 & -1.26 & 0.35 \\
\hline $2 \mathrm{H}-3,85-89$ & 7.85 & -3.12 & -0.18 \\
\hline $2 \mathrm{H}-4,85-89$ & 9.35 & -0.02 & 0.06 \\
\hline $2 \mathrm{H}-5,85-89$ & 10.85 & -0.34 & 0.89 \\
\hline $2 \mathrm{H}-6,85-89$ & 12.35 & 0.03 & 0.74 \\
\hline $3 \mathrm{H}-1,84-88$ & 14.34 & -0.75 & 0.99 \\
\hline $3 \mathrm{H}-2,84-88$ & 15.84 & -0.01 & 0.73 \\
\hline $3 \mathrm{H}-3,85-89$ & 17.35 & -1.73 & 0.95 \\
\hline $3 \mathrm{H}-4,85-89$ & 18.85 & -0.34 & 0.79 \\
\hline $3 \mathrm{H}-6,85-89$ & 21.85 & -1.01 & 0.53 \\
\hline $4 \mathrm{H}-1,85-89$ & 23.85 & -0.23 & 1.11 \\
\hline $4 \mathrm{H}-2,85-90$ & 25.35 & -0.55 & 0.73 \\
\hline $4 \mathrm{H}-3,85-90$ & 26.85 & -0.29 & 0.71 \\
\hline $4 \mathrm{H}-6,85-90$ & 31.35 & -0.28 & 1.16 \\
\hline $5 \mathrm{H}-1,85-90$ & 33.35 & -0.57 & 0.41 \\
\hline $5 \mathrm{H}-3,85-90$ & 36.35 & -0.70 & 0.75 \\
\hline $5 \mathrm{H}-5,85-90$ & 39.35 & 0.49 & 0.52 \\
\hline $6 \mathrm{H}-5,84-89$ & 48.10 & -0.33 & 0.70 \\
\hline 7H-1, 84-89 & 49.60 & -0.06 & 0.46 \\
\hline 7H-2, 84-89 & 52.34 & -0.06 & 0.77 \\
\hline 7H-3, 84-89 & 53.84 & 0.11 & 0.54 \\
\hline 7H-4, 84-89 & 55.34 & -0.28 & 0.62 \\
\hline 7H-6, 84-89 & 56.84 & 0.30 & 0.82 \\
\hline $8 \mathrm{H}-1,84-89$ & 61.84 & -1.39 & 0.88 \\
\hline $8 \mathrm{H}-2,84-89$ & 63.34 & -0.74 & 0.70 \\
\hline $8 \mathrm{H}-4,84-89$ & 66.34 & -0.57 & 0.98 \\
\hline $9 \mathrm{H}-2,85-89$ & 72.85 & -0.62 & 0.34 \\
\hline $9 \mathrm{H}-3,85-89$ & 74.35 & -1.54 & 0.31 \\
\hline $9 \mathrm{H}-4,85-89$ & 75.85 & -1.52 & 0.87 \\
\hline $10 \mathrm{H}-1,84-89$ & 80.84 & 0.12 & 0.25 \\
\hline $10 \mathrm{H}-3,84-89$ & 83.84 & -0.77 & 0.51 \\
\hline $10 \mathrm{H}-4,82-87$ & 85.32 & -1.91 & 0.52 \\
\hline $10 \mathrm{H}-5,84-89$ & 86.84 & 0.53 & 0.76 \\
\hline $10 \mathrm{H}-6,84-89$ & 88.34 & 0.14 & 0.60 \\
\hline $11 \mathrm{H}-1,84-90$ & 90.34 & -3.02 & 0.50 \\
\hline $11 \mathrm{H}-6,84-90$ & 95.44 & 0.19 & 0.65 \\
\hline $11 \mathrm{H}-7,84-90$ & 96.94 & -0.89 & 1.00 \\
\hline $12 \mathrm{H}-1,84-89$ & 99.84 & -1.27 & 0.65 \\
\hline $12 \mathrm{H}-6,84-89$ & 107.34 & -1.43 & 0.64 \\
\hline $14 \mathrm{H}-1,84-89$ & 117.14 & -1.65 & 0.81 \\
\hline $14 \mathrm{H}-2,84-89$ & 118.64 & -1.22 & 1.05 \\
\hline $14 \mathrm{H}-3,84-89$ & 120.14 & -0.27 & 1.66 \\
\hline $14 \mathrm{H}-5,84-89$ & 123.14 & -1.65 & 1.25 \\
\hline $15 \mathrm{H}-1,85-89$ & 125.65 & -1.46 & 1.18 \\
\hline $15 \mathrm{H}-2,85-89$ & 127.15 & -1.21 & 1.10 \\
\hline $15 \mathrm{H}-3,83-89$ & 128.63 & 0.04 & 0.48 \\
\hline $15 \mathrm{H}-4,82-86$ & 130.12 & -1.61 & 0.73 \\
\hline
\end{tabular}

\begin{tabular}{|c|c|c|c|}
\hline $\begin{array}{l}\text { Core, section, } \\
\text { interval }(\mathrm{cm})\end{array}$ & $\begin{array}{l}\text { Depth } \\
\text { (mbsf) }\end{array}$ & $\begin{array}{l}\delta^{18} \mathrm{O} \\
(\% o)\end{array}$ & $\begin{array}{l}\delta^{13} \mathrm{C} \\
(\% 0)\end{array}$ \\
\hline $15 \mathrm{H}-5,90-94$ & 131.70 & -0.99 & 0.85 \\
\hline $15 \mathrm{H}-6,85-89$ & 133.15 & -1.33 & 0.74 \\
\hline $16 \mathrm{H}-1,84-89$ & 135.14 & -0.34 & 1.19 \\
\hline $16 \mathrm{H}-2,85-90$ & 136.65 & -0.81 & 0.88 \\
\hline $16 \mathrm{H}-3,90-96$ & 138.20 & -0.94 & 0.96 \\
\hline $16 \mathrm{H}-4,84-90$ & 139.64 & 0.20 & 0.43 \\
\hline $17 \mathrm{H}-1,85-90$ & 142.85 & -0.24 & 0.63 \\
\hline $17 \mathrm{H}-5,85-90$ & 146.41 & -0.80 & 0.61 \\
\hline $17 \mathrm{H}-6,85-90$ & 147.91 & -1.07 & 1.03 \\
\hline $17 \mathrm{H}-7,85-90$ & 149.41 & -1.13 & 1.21 \\
\hline $18 \mathrm{H}-1,85-90$ & 150.75 & -0.44 & 0.80 \\
\hline $18 \mathrm{H}-4,84-90$ & 155.24 & -1.43 & 0.93 \\
\hline $18 \mathrm{H}-5,84-89$ & 156.74 & -0.08 & 1.18 \\
\hline $19 \mathrm{H}-1,84-89$ & 158.64 & -1.39 & 0.54 \\
\hline $19 \mathrm{H}-2,85-89$ & 160.15 & -1.30 & 1.13 \\
\hline $19 \mathrm{H}-3,84-89$ & 161.64 & -0.88 & 0.73 \\
\hline $19 \mathrm{H}-4,80-85$ & 163.10 & -0.86 & 1.36 \\
\hline $19 \mathrm{H}-5,90-95$ & 164.70 & -0.89 & 1.17 \\
\hline $19 \mathrm{H}-6,84-89$ & 166.14 & -1.28 & 1.50 \\
\hline $20 \mathrm{H}-1,84-89$ & 167.54 & -1.12 & 1.22 \\
\hline $20 \mathrm{H}-2,84-89$ & 169.04 & -0.23 & 0.73 \\
\hline $20 \mathrm{H}-3,84-89$ & 170.54 & -1.50 & 1.51 \\
\hline $20 \mathrm{H}-4,84-89$ & 172.04 & -1.48 & 1.35 \\
\hline $20 \mathrm{H}-5,84-89$ & 173.54 & -0.42 & 0.52 \\
\hline $21 \mathrm{H}-2,84-90$ & 176.84 & -0.59 & 0.32 \\
\hline $21 \mathrm{H}-3,87-92$ & 178.37 & -2.64 & 0.43 \\
\hline $21 \mathrm{H}-4,84-90$ & 179.84 & -2.10 & 0.66 \\
\hline $21 \mathrm{H}-5,83-88$ & 181.33 & -1.16 & 1.24 \\
\hline $22 \mathrm{H}-1,84-89$ & 183.14 & -1.72 & 0.77 \\
\hline $22 \mathrm{H}-2,84-89$ & 184.64 & -0.72 & 0.97 \\
\hline $22 \mathrm{H}-3,84-89$ & 186.14 & -2.23 & -0.12 \\
\hline $22 \mathrm{H}-4,84-89$ & 187.64 & -0.92 & -0.07 \\
\hline $23 \mathrm{H}-2,65-69$ & 191.15 & -2.28 & 0.34 \\
\hline $23 \mathrm{H}-4,85-89$ & 194.35 & -1.67 & 0.42 \\
\hline $23 \mathrm{H}-5,85-89$ & 195.85 & -1.90 & 1.08 \\
\hline $23 \mathrm{H}-6,85-89$ & 197.35 & -1.47 & 0.57 \\
\hline $24 \mathrm{H}-1,84-89$ & 199.34 & -2.04 & 0.84 \\
\hline $25 \mathrm{H}-2,85-89$ & 203.40 & -0.19 & 0.22 \\
\hline $25 \mathrm{H}-5,85-89$ & 207.90 & -0.60 & 0.18 \\
\hline $25 \mathrm{H}-6,85-89$ & 209.38 & -0.77 & 0.10 \\
\hline $26 \mathrm{H}-1,84-89$ & 211.14 & -0.75 & 0.23 \\
\hline $27 \mathrm{H}-3,84-89$ & 217.94 & -1.01 & 0.15 \\
\hline $27 \mathrm{H}-4,84-89$ & 219.44 & -1.28 & 0.59 \\
\hline $28 \mathrm{H}-2,84-89$ & 222.64 & -2.45 & 0.27 \\
\hline $28 \mathrm{H}-3,84-89$ & 224.14 & -1.26 & 0.37 \\
\hline $28 \mathrm{H}-4,81-85$ & 225.61 & -1.96 & 0.18 \\
\hline $29 \mathrm{H}-2,82-87$ & 229.42 & -1.42 & -0.25 \\
\hline $29 \mathrm{H}-4,79-84$ & 232.39 & -0.46 & 0.40 \\
\hline $29 \mathrm{H}-5,81-86$ & 233.91 & -0.58 & 0.07 \\
\hline
\end{tabular}

